\title{
WOMEN IN LEADERSHIP: INTERROGATING ASSOCIATED COVERT AND OVERT PARANOIA
}

\author{
Samuel O. Chukwu-Okoronkwo \\ http://dx.doi.org/10.4314/og.v15i1.11s
}

\begin{abstract}
The issue of gender and leadership, especially of women in leadership, has undoubtedly remained a crucial subject matter of discussion in contemporary politics and leadership not only in Africa, but globally too. Scholars have made several attempts to express their different shades of opinions regarding the issue based on their individual consciousness and understanding of the issue as the case may be. This has thus given rise to the prevailing scale of mixed feelings that always surround discussions about the issue; thus entrenching a strong feeling of paranoia about it. Through qualitative research approach, explored through observation and analytical literature review, and further anchored on the Functional Leadership Theory, the paper interrogates the covert and overt manifestations of the feeling of paranoia that often attend the issue of women in leadership generally. It makes a case for not only integrating women in leadership positions in every sphere of life in the society, but also in giving them a chance at the top where it really matters.
\end{abstract}

Keywords: Gender, Leadership, Male Chauvinism, Paranoia, Patriarchy, Politics, Women

\section{Introduction}

Bass (1990), a distinguished professor and director of the Centre for Leadership Studies at the State University of New York, has noted that leadership is a highly complicated and modern concept. Perhaps, due to this complexity associated with the concept, the view that there are as many definitions of leadership as there are leaders has continued to hold sway. With this prevailing subjective perception to the definition of leadership as noted above, therefore, the fact that the term has so many definitions may not be surprising either as this multiplicity of definitions may also not be unconnected to the various perspectives of fields of endeavour from which it could be 
Ogirisi: a new journal of African studies vol. 15s 2019

considered. Albrecht (1996) in his book, Creating Leaders for Tomorrow, noted that "leadership is the capability to focus human energy to achieve defined outcomes" (p. 16). Stogdill's (1950) rather frequently cited definition of leadership sees leadership as an influencing process aimed at goal achievement. Aina (2002) presents the following management perspective definitions of leadership:

(i) as the process of influencing others to work willingly to achieve organisational goals, rather than out of fear; and

(ii) as a dynamic process in a group whereby one individual influences others to contribute to the achievement of group tasks. (p.207)

Similarly, Bass sees leadership as a focal point of group purposes and notes that it is "a form of persuasion, an interactive relationship(s), and a propensity to achieve goals or bring about results" (cited in Young (n/d), p.3). A common salient point worthy of note about the multiplicity of the definitions of leadership, however, is the fact that it is a process - a process which involves directing the behaviour of others towards the accomplishment of objectives. Stogdill (1950) sees leadership as the process or act of influencing the activities of an organized group in its efforts toward goal setting and achievement. The implication is that leadership is considered as a task-oriented undertaking aimed at setting direction for a team or group. The central focus of leadership, therefore, is getting things accomplished through people. Since this paper focuses on the theme of gender and leadership, it is pertinent to further this discussion by identifying first and foremost who the leader is, with particular emphasis on the associated roles; and then try to determine exactly what gender has to do with such roles. Deriving from the foregoing definitions of leadership, especially as touching on influence in motivating people towards goal accomplishment, a leader, therefore, can conveniently be considered as the person on whom the onus of exerting the influence falls upon - the one who influences a group of people to work towards the realization of goals. Hence, the capacity to influence others towards accomplishment of goals and betterment is what defines the hallmark of leadership. To summarize the foregoing definitions of leadership, therefore, is to say that leadership is simply influence. 
Chukwu-Okoronkwo: Women in Leadership ...

The researcher, while preparing this paper, had the privilege of listening to a post on WhatsApp of an instructor who gave an apt mnemonic interpretation of influence and how it works which is considered very instructive in the context of this discussion, as hence summarized as follows:

- Integrity: doing what is right in spite of the forces against you.

- Nurturing your followers: empowering the young ones. Leadership is not a permanent position. Somebody has got to be prepared to take over the mantle of leadership.

- Faith: have faith in your followers.

- Listening to your followers: have a listening ear. People want to be listened to.

- Understanding heart: some leaders have a heart of stone. We are committed to die for leaders who have understanding heart.

- Emotionally intelligent: be sensitive to your environment...to the needs of the people who are following you.

- Navigating your followers through trouble.

- Communication skill

- Exemplary: must be exemplary in leadership.

\section{The Roles of a Leader}

Patrick (2017), in outlining the following roles of a leader, also points to a few dimensions of influence as highlighted above:

1. Motivator: Influences others to act in an advantageous manner.

2. Mentor: Provides the mentee with the right foundation for success.

3. Learner: Constantly develops his/her knowledge, skills and abilities to help the organization achieve its strategic goals.

4. Communicator: Listens to incoming messages effectively and articulates what being stated to others in an understandable, concise manner.

5. Navigator: Acts as a compass. He creates the vision for the organization to advance toward its mission. 
In addition to the foregoing, the leader must know who he/she is, have a vision that is well articulated and communicated, build trust among colleagues, and take effective action to see that group objectives are realized.

\section{Gender and Leadership Question}

Gender and leadership question is simply an interrogation of the relationship between gender and leadership. Precisely, it seeks to determine exactly what leadership has to do with gender. To do this, therefore, is to also understand what gender is, having earlier highlighted what leadership is. Gender, according to Duru (2014), simply refers to "masculinity and femininity" (p.11). Here, masculinity is seen as a social consideration that is appropriate for male, which includes traits as physical features, boldness, aggressiveness, strength, fearlessness among other; while femininity on the other hand is just the opposite, and includes those socially defined and observed attributes that are deemed appropriate for females with such descriptions as care, tenderness of heart, emotion, physical weakness and other body features by which a female could be identified. It is, perhaps, in the light of the above socially constructed specifications about gender that Duru has further defined it as "the amount of masculinity or femininity in a person" (p.12). The World Health Organization (WHO) also reinforces gender's social construction base by describing it as referring to the socially constructed roles, behaviours, activities, and attributes that a given society considers appropriate for men and women. As a product of social creation, therefore, which is defined, supported and reinforced by its (social) structures and institutions, the implication is that gender involves the process of sorting out individual members of society into sexes - males and females - as purposively enforced by patriarchy, to create a dichotomy. Now, in the light of our understanding of the meaning of leadership, who the leader is as well as what the functions are, the crucial questions, therefore, are: Is leadership gender specific? Why has it always been considered from such male-centric perspective? What has gender got to do with it?

In order to find possible answers to the above questions and therefore reorient our consciousness to some erroneous perceptions about the relationship between gender and leadership, the researcher 
Chukwu-Okoronkwo: Women in Leadership ...

considers it pertinent to anchor this study on the Functional Leadership Theory (Hackman \& Walton, 1986; McGrath, 1962), which addresses specific leader behaviours in contributing to organizational or unit effectiveness. The model focuses on how leadership occurs, rather than on who does the leading (Shead, 2019). It defines the types of behaviours that guide an organization and then looks at how those behaviours occur. Under this model, leadership is considered as a distributed function and not as fully dependent on a single individual; but rather as based on a sequence of behaviours by a group. Though there are other important details about the functional leadership model, however, the main concern of this study is its focus on 'how' instead of 'who' in relation to leadership. This concern is informed by the fact that the Functional Leadership Theory places greater emphasis on how an organisation or task is being led rather than who is assigned the leadership role. The implication is that who the leader is, be it man or woman, male or female, does not necessarily matter; rather, what really matters is what he or she does, and to what effect. What skill or talent is such a leader taking into leadership? How functional, or to state appropriately, effective is such a leader in guiding others to achieve organisational goals? The Functional Leadership Theory is invariably a result-oriented leadership model.

However, with the prevailing professional, political and socio-cultural gender realities of our time, particularly in leadership, The Economic Times (2018), citing a recent study, has noted that prejudice against women is greater than we might think. The report stresses that gender stereotypes and gender-oriented prejudice pose a serious threat to women's careers and facilitate gender bias not only in the workplace, but also in every other place where it matters (additional emphasis). It further cites theorists as tracing the emergence of prejudice against women leaders to the incongruity between their gender role and the more masculine social role of a leader. Who, if I may ask, assigns or designates these roles?

With particular reference to the result-oriented base of the Functional Leadership Theory, therefore, it is not surprising to note that women are gradually and steadily making their result-oriented leadership presence felt in academia, entrepreneurship, administration, politics, education, engineering, health, among other vital areas, as Okafor, Fagbemi and Hassan (2011) have 
corroborated. Their exploits are not only limited to regional and national fronts, but also extends to global fronts. They are now consciously and conscientiously breaking the traditional glass ceiling that barred them from entering into leadership positions even if they possessed requisite skills and talent to occupy them and are constantly evolving and reaching new milestones across a wide spectrum of human activities in modern times (Tutorial Point, 2019). The world generally, therefore, has witnessed the advent of women leaders such as Hillary Rodham Clinton, Indra Nooyi, Oprah Winfrey, Theresa May, Christine Lagarde, to name a few. On the home front, the exploits of women like Professor (Mrs.) Grace Alele-Williams, the first female Vice-Chancellor in a Nigerian university; late Prof. Dora Nkem Akunyili (OFR), the former Director of National Agency for Food and Drug Administration and Control and Dr. (Mrs.) Ngozi Okonjo-Iweala among others, are worthy of note. However, despite these manifest exploits by women leaders, why has governance/leadership in most African nations continued to bear a masculine face, with women merely serving as stooges, and often manipulated by men?

\title{
Preamble: An Anecdote
}

The scenario encapsulates incidents surrounding electioneering activities in a typical educational environment where a woman for the first time in the history of an institution's staff union elections declares interest to contest for the position of the Chairperson, a position that has hitherto been dominated by male contestants. The scale of mixed feelings that surrounded discussions about her declaration of interest, the covert and overt feeling of paranoia it generated, the election proper and its outcome, all culminated in giving impetus to this paper.

\section{Interrogating the Covert and Overt Paranoia that often attend the Issue of Women in Leadership}

\author{
Is anyone actually afraid of a woman leader? \\ ...Who is that person?
}

This section critically probes the covert and overt manifestations of feeling of paranoia that often accompany the issue 
Chukwu-Okoronkwo: Women in Leadership ...

of women in leadership by focusing on observations from the antecedents of the foregoing anecdote. As noted in the anecdote, for the first time in the history of an institution's staff union elections, a woman suddenly emerges to declare interest to contest for the post of the Chairperson, a position that was hitherto dominated by male contestants; thus, triggering off a scale of mixed feelings and paranoia that culminated into the inconceivable outcome of the election.

\section{Observations}

The following observations which emerged from the antecedents of the preceding anecdote, unarguably, encapsulate the covert and overt manifestations of feeling of paranoia that often surround the issue of women in leadership:

i. Some members of staff, both men and women, and especially women, appeared to be excited about the development, while some others, especially men, appeared to be inexplicably uncomfortable which is rather suggestive of being threatened.

ii. To some men, the emergence of a woman to contest for that most coveted seat was rather an act of over-ambitiousness, and certainly an unacceptable affront to male chauvinism/authority.

iii. Despite the obvious excitement among majority of women about the development, a few still felt that the emerging woman's aspiration was also a step taken too far and that it would have been more sensible for the generality of women to just remain in their present submissiveness and continue to play second fiddle roles.

iv. The outcome of the election was not only inconceivable, but also a strong statement on the hypocrisy of men - that of 'men' and 'women' alike.

\section{Discussion}

In the light of the above observations, it is understandable to first and foremost note that those who expressed excitement, perhaps, did so because at last change was coming their way, especially the women, as one of them had decided to take up the challenge of 
upturning the status quo; hence, their predictable response at drumming support for her. Those who appeared otherwise might have done so because of some inexplicable fearful feelings which can only be explained by their sheer paranoia, which were expressed both covertly and overtly. Here, paranoia is seen as a tendency on the part of an individual or group toward excessive or irrational suspiciousness and distrustfulness of others; for that was actually what those reactions seemed to portray. In other words, paranoia involves intense fear or suspicion, especially when unfounded. This corroborates the observation by Raihani and Bell (2017) about the two key components of paranoia which are: (i) unfounded ideas of harm, and (ii) the idea that the harm is intended by others. A paranoid person typically has a biased perception of reality.

For those who felt that the emergence of a woman to contest for the most coveted seat in a staff union election was rather an act of over-ambitiousness and an unacceptable affront to male chauvinism/authority, they are certainly chauvinists who are not in conformity with the reality of the dynamics of the 21 st Century. A chauvinist, as Ingraham (2014) has defined, is "a male who patronizes, disparages, or otherwise denigrates females in the belief that they are inferior to males and thus deserving of less than equal treatment or benefit" (p.1). Ingraham further traces this obvious fear of women in leadership to men who hate women, men who mistreat women, men who use and abuse women, and certainly men who think that women are less than them. This, perhaps, explains the reason why women, as a rule, did not assume leadership positions in most communities and settings no matter how fervent they craved for it. It is, therefore, only the dynamism of our thoughts and actions that will prove our adaptability to the progressiveness of the $21 \mathrm{st}$ Century. Otherwise, how else could women prove their capabilities in leadership in our contemporary society if not when they are given equal opportunities like their men counterparts?

Furthermore, despite the obvious excitement among majority of women about the emergence of the woman to vie for that exalted position, it is only surprising that a few still felt that the woman's aspiration was a step taken too far. It is also unimaginable to think that a woman should hold such defeatist opinion that it would have been more sensible for the womenfolk to remain in their present submissiveness and continue to play second fiddle roles than 
Chukwu-Okoronkwo: Women in Leadership ...

sticking out their neck; which only portrays the level of low selfesteem to which some women hold themselves and their folks alike. This also explains why it would be difficult for such women to believe in the capability of any other woman talk less of supporting the person or believing in themselves either. Hence, it is undoubtedly the likes of such pessimistic women that Ezeigbo (1996) had in mind when she aptly asserted that "the "silencing" of women which further led to their "invisibility" was encouraged by their own tendency to...accept the status quo and their lack of political will to change the situation" (p.15).

On the eventual election and its outcome, it was not just inconceivable and baffling too that the woman got a ludicrously insignificant count of votes, compared to her male counterparts, but the reality was also a very strong statement on the hypocrisy of men - that of men and women alike. Most of the women who enthusiastically drummed their support for her at her emergence were nowhere to be found when it mattered most. Their support did not go beyond lip service. Those who attempted to show up did not have the will-power to actually demonstrate their support by translating it to vote during the election, despite their good number. What an absurd complicity, either consciously or unconsciously, at inflicting injury on oneself or rather 'one's folk/kind'. How can one choose to play complicit to her own subjugation and suppression? What a self-sabotage? Ironically, it hardly ever even occurred to such generality of masses of women that they could advantageously use their numerical strength to challenge such forces of subjugation and suppression. It is only pitiable! Some men too who openly saluted the woman's courage at her emergence and gave their assurance to be counted on for support, did not do so beyond lip service either. They only proved that they could not be relied upon as their promises did not come from their hearts. All their sham support was but mere eye service.

\section{Conclusion}

The experience of the woman aspirant to that exalted leadership position, by no exaggeration, is the collective experience of womenfolk; and her fate, the collective fate of all women as far as leadership is concerned in our contemporary society. This situation, for theorists of gender oppression, is basically that of sheer 
domination and oppression by men (Ritzer, 2008). It is, therefore, only absolutely unfortunate and ironical, in this age and time, as Ingraham graphically and aptly captures it, that "A few men would easily salute their mothers, showcase their wives and brag about their daughters, but none of whom are good enough to lead" (1). What a warped mentality? But why in the first place would anybody feel threatened that a woman is out to contest for the most coveted post in a staff union election? Why would anyone be afraid of a woman leader? Why would her emergence be considered an affront on male chauvinism and authority and an anathema that cannot be condoned? Is the woman less human that the man that she cannot be considered fit for a leadership position in this 21st Century? What has gender got to do with leadership?

Ingraham does not only recognize the reality of this fear of women in leadership, but also traces it to men who hate women, men who mistreat women, men who use and abuse women, and certainly men who think that women are less than them. In the light of the foregoing, it is the position of this paper that who the leader is, be it man or woman, does not necessarily matter; rather, what really matters is what he or she does, and to what effect, the skill or talent he/she takes into leadership, and his/her effectiveness in guiding others to achieve organisational goals. Therefore, it is high time these men freed their minds from such hate, such mistreat, such use and abuse, and indeed, such denigrating of women and not only start integrating them in leadership positions in every sphere of life in the society, but most importantly to start giving them a chance at the top where it really matters by according them due status and rights to enable them participate actively.

\section{*Samuel O. Chukwu-Okoronkwo, PhD}

Department of Mass Communication

Abia State University, Uturu.

Email:sam_okoronkwo@yahoo.com 
Chukwu-Okoronkwo: Women in Leadership ...

\section{References}

Aina, S. (2002). Modern media management. Abeokuta: Ebensun Publishers.

Albrecht, K. (1996). Creating leaders for tomorrow. Portland, OR: Productivity Press.

Bass, B. M. (1990). Bass and Stogdill's handbook of leadership: Theory, research, \& managerial applications. New York: The Free Press.

Duru, F. A. (2014). Women and society. Enugu: Rhyce Kerex Publishers.

Ezeigbo, T. A. (1996). Gender issues in Nigeria: A feminist perspective. Lagos: Vista Books Ltd.

Hackman, J. R. \& Walton, R. E. (1986). Leading groups in organizations, in P. S. Goodman \& Associates (Eds.), Designing effective work groups $(72-119)$. San Francisco, CA: Jossey-Bass.

Ingraham, I. W. (2014). "Weak men fear women leaders". The Tribune, June, 18. Accessed on 20 September, 2019 from https://www.tutorialspoint.com/women_in_leadership/wome n_in_leadership_introduction.htm

Janse, B. (2019). "Functional leadership model". Accessed on 8 October 2019 from toolshero: https://www.toolshero.com/leadership/functional-leadershipmodel/

Kasomo, D. (2012). "Factors affecting women participation in electoral politics in Africa". International Journal of Psychology and Behavioural Sciences 2(3): 57 - 63.

McGrath, J. E. (1962). Leadership behavior: Some requirements for leadership training. U. S. Civil Service Commission, Office of Career Development. Washington, DC.

Okafor, E. E. \& Akokuwebe, M. E. (2015). Women and leadership in Nigeria: Challenges and prospects. Developing Country Studies, 5(4): 1 - 10.

Okafor, E. E; Fagbemi, A. O. \& Hassan, A. R. (2011). Barriers to women leadership and managerial aspirations in Lagos, Nigeria: An empirical analysis. African Journal of Business Management, 5(16): 6717 - 6726. 
Ogirisi: a new journal of African studies vol. 15s 2019

Okonjo-Iweala, N. (2018). Fighting corruption is dangerous: The story behind the headlines. Cambridge, MA: The MIT Press.

Patrick, C. (2017). "Five roles of a leader". Accessed on 3 October, 2019 from https://www.usi.edu/outreach/engage/2017archives/five-roles-of-a-leader/

Raihani, N. J. \& Bell, V. (2017). Paranoia and the social representation of others: A large-scale game theory approach. Scientific reports, 7(1): $1-9$.

Ritzer, G. (2008). Sociological theory (7th ed.) New York: McGrawHill

Shead, M. (2019). The functional leadership model. Accessed on 9 October, 2019 from http://www.leadership501.com/functional-leadershipmodel $/ 20 /$

Stogdill R. M. (1950). Leadership, membership and organization. Psychol Bull, 47: 1 - 14.

The Economic Times (8 November, 2018). "Boardroom drama: More men believe women are less qualified for leadership roles". Accessed on 27 September, 2019 from https://economictimes.indiatimes.com/magazines/panache/b oardroom-drama-more-men-believe-women-are-lessqualified-for-leadershiproles/articleshow/66523598.cms?from $=\mathrm{mdr}$

Tutorial Point (2019). "Women in leadership". Accessed on 29 September, 2019 from https://www.tutorialspoint.com/women_in_leadership/wome n_in_leadership_quick_guide.htm

World Health Organisation. Gender, women and health: What do we mean by "sex" and "gender"? Accessed on 7 October, 2019 from http://apps.who.int/gender/whatisgender/en/.

Young, R. D. (n/d). "Leadership: Toward a visionary approach". Accessed on 15 July, 2019 from http://www.ipspr.sc.edu/publication/Leadership_Toward_a_ Visionary_Approach.doc 